\title{
"We teach them the ways we can...": educational practices for immigrant children in elementary schools in Russia
}
"Nós os ensinamos como podemos...": Práticas educacionais para crianças imigrantes em escolas primárias na Rússia

\section{“Les enseñamos cómo podemos...": Prácticas educativas para niños inmigrantes en escuelas primarias de Rusia}

ORCID: http://orcid.org/0000-0002-5134-4159

Rezeda Khairutdinova

ORCID: $h$ ttp://orcid.org/0000-0002-8878-1926

Aydar Kalimullin

ORCID: https://orcid.org/0000-0001-7788-7728

Dina Birman

ORCID: http://orcid.org/0000-0003-2513-3048

\begin{abstract}
The aim of this research was to identify the educational practices that elementary school teachers use in working with immigrant children for linguistic and academic support purposes. Empirical data were collected through interviews with twenty elementary school teachers. The interviews were analyzed using inductive and deductive content analysis methods. The measures to create a favorable atmosphere in the classroom and the psychological comfort of the child include practices to promote respect for different ethnicities, developing intercultural communication skills. In the absence of institutionalized structures, teachers take the initiative to adapt their teaching and instructional methods when working with immigrant children. The inclusion of parents in the educational process can be used in all directions of the practices of teachers with immigrant children. In the context of Tatarstan, the teaching of Russian as a foreign language is possible through the Tatar language, which belongs to the Turkish language family. The native languages of most immigrants arriving in Tatarstan also belong to the Turkish language family.
\end{abstract}

Keywords: teachers' educational practices, immigrant children, language support, academic support, promotion of a favorable climate

Resumo: O objetivo da presente pesquisa foi identificar as práticas educativas que os professores do ensino fundamental utilizam no trabalho com crianças imigrantes para fins linguísticos e de apoio acadêmico. Os 
dados empíricos foram coletados por meio de entrevistas com vinte professores do ensino fundamental. As entrevistas foram analisadas por meio de métodos de análise de conteúdo indutiva e dedutiva. As medidas para a criação de um clima favorável na sala de aula e o conforto psicológico da criança incluem práticas de promoção do respeito às diferentes etnias, desenvolvendo habilidades de comunicação intercultural. $\mathrm{Na}$ ausência de estruturas institucionalizadas, os professores tomam a iniciativa de adaptar seus métodos de ensino e instrução ao trabalhar com crianças imigrantes. A inclusão dos pais no processo educacional pode ser usada em todas as direções das práticas dos professores com crianças imigrantes. No contexto do Tartaristão, o ensino do russo como língua estrangeira é possível por meio da língua tártara, que pertence à família das línguas turcas. As línguas nativas da maioria dos imigrantes que chegam ao Tartaristão também pertencem à família das línguas turcas.

Palavras-chave: Práticas educacionais de professores. Filhos imigrantes. Apoio linguístico. Apoio acadêmico. Promoção de um clima favorável.

Resumen: El objetivo de esta investigación fue identificar las prácticas educativas que utilizan los maestros de primaria en el trabajo con niños inmigrantes con fines de apoyo lingüístico y académico. Los datos empíricos se recopilaron a través de entrevistas con veinte maestros de escuela primaria. Las entrevistas se analizaron utilizando métodos de análisis de contenido inductivos y deductivos. Las medidas para crear un ambiente favorable en el aula y el confort psicológico del niño incluyen prácticas para promover el respeto a las diferentes etnias, desarrollando habilidades de comunicación intercultural. En ausencia de estructuras institucionalizadas, los maestros toman la iniciativa de adaptar sus métodos de enseñanza e instrucción cuando trabajan con niños inmigrantes. La inclusión de los padres en el proceso educativo se puede utilizar en todas las direcciones de las prácticas de los profesores con niños inmigrantes. En el contexto de Tartaristán, la enseñanza del ruso como lengua extranjera es posible a través del idioma tártaro, que pertenece a la familia del idioma turco. Las lenguas nativas de la mayoría de los inmigrantes que llegan a Tartaristán también pertenecen a la familia de las lenguas turcas.

Palabras claves: Prácticas educativas de los professores. Niños inmigrantes. Apoyo linguístico. Apoyo académico. Promoción de un clima favorable.

\section{INTRODUCTION}

Russia has one of the highest numbers of immigrants, although immigration is a relatively new phenomenon for the country. According to the Ministry of Internal Affairs (The Ministry of internal Affairs 2018) the number of registeredimmigrants in Russia as of June 2018 is 6.993 .602 people.

The largest migration flows are fromUzbekistan $(3,446,849)$, Tajikistan $(1,745,554)$, China $(1,437,891)$, Ukraine $(1,319,051)$, Kyrgyzstan $(620,417)$, Kazakhstan $(502,420)$, Azerbaijan $(490,265)$ and Armenia $(490,168)$. There is no statistical data regarding migrant children in Russia. According to the Committee for Education (Dudko 2014), the percentage of children of immigrants is higher in small schools (not more than 400 students), and there are no more than $5 \%$ of them in big schools. In a significant number of Russian schools there are no immigrant children (Alexandrov et al. 2012, 15).

In accordance with the Russian legislation immigrant children are entitled to receive education in any school in Russia. Chapter 1, Article 5 of the law "On Education in the Rus- 
sian Federation" (2013) states: "1. There is a guaranteed right to education for every person in the Russian Federation. 2. The right to education in the Russian Federation is guaranteed regardless of the sex, race, nationality, language, origin, property, social and official status, place of residence, religion, beliefs, membership in public groups or any other circumstances".According to the data of Russian Education Fund, however, about $80 \%$ of immigrant children do not attend kindergartensdueto the issues with registration and shortage of places. Also according to the same source, every third immigrant child does not have an access to education, while in 2011 only every tenth child did not have that opportunity (Dudko 2014). Although every child has a right to education,the right relates only to legal residents. According to the law, foreign children are allowed to attend educational institutions in Russia only if they hold a residence permit (Zhukova 2015).

Presence of even a few immigrant children in school requires provision of special conditions and special approaches to the learning process. The Russian studies on adaptation of immigrant children highlight the fact that there are still no institutionalized practices of inclusion and adaptation of immigrant children to a new educational environment and a new culture (Alexandrov, et al. 2012; Zborovsky and Shuklina 2013). Therefore, teachers play the key role in that process. They are responsible for language and sociocultural adaptation of immigrant children. It is, therefore, of a crucial importance to examine how teachers work in multicultural classes in Russia.

Teaching practice, or pedagogy, is known as the art of being a teacher, or a science of teaching. It generally includes strategies, styles, context of instruction, and teachers' actions in the classroom (Herrera 2010).

Practices used for teaching immigrant children are closely related to the difficulties of their adaptation to a new culture. Previous studies elaborate on difficulties which immigrant children face in a new culture. The difficulties are related to learning a new language, a new culture, coping with the immigration trauma, different school requirements and academic standards (Vedder, Boekaerts, and Seegers 2005; Raviv et al. 1990; Birman 2002).

Educational practices used with immigrant children can be studied on the institutional, personal, and instructional levels (Richards, Brown, and Forde 2007). Institutional level includes practices used at school. Personal level includes teachers' actionsas of a culturally responsive person. Instructional level includes teaching strategies and methods. While teachers do not directly influence educational policies, they are proactively involved in the educational process with immigrant children on institutional, personal and instructional levels.

Christensen and Stanat (2007) single out the following types of language support provided to migrant children in different countries: (1) immersion - immigrant students are not provided with any language support and study in regular classes; (2) immersion with a systematic support - immigrant students study in a regular class but they are provided with a language support for a certain period of time; (3) immersion with a preparatory phase immigrant students attend preparation courses before joining a regular class; (4) transitional 
bilingual - immigrant children study in their native language before gradually moving to study in the language of the host country; (5) maintenance bilingual - immigrant children are learning in their native language.

Dumcius et al., (2012) identify the following models of educational support provided in some European countries: (1) compensatory support, i.e. oral translation for parents, teaching the host country language and teaching the native language for large groups of migrants; (2) non-systematic support, according to which the state does not adopt any rules regarding education of immigrant children. Fragmentary support can be initiated by the school; (3) comprehensive support includes linguistic and academic support; (4) integrative model when students continue to study their native languagethroughout the entire learning process. Additionally, a lot of attention is paid to intercultural education; (5) centralized model suggests the use of linguistic,academic support, an intercultural component and a developed grading system to be adopted at a state level. These support models differ from each other not only in the focused responsibility zone (school/education system) but also in the comprehensive character of the support. If the first model offers only language support to immigrant children, the third model comprises linguistic and academic support. The fourth model provides psychological and sociocultural support. The fifth model includes all the types of educational support that immigrant children need. These support models also influence teachers' instructions and actions. We will further examine the respective directions of work.

The first and the most important direction is the study of a new culture which primarily means learning a new language. Teaching a host country language as a second language is the most successful strategy compared to the traditional methods used when teaching native speakers (Zheleznyakova 2011; Kudryavtseva and Volkova 2013; Herrelland Jordan 2016; Levine, Lukens, and Smallwood 2013). A number of approaches can also be distinguished in teaching a second language. The first approach means teaching only the language of the host country; that includes speaking, writing, team work and discussions (Gibbons 2015; Levine, Smallwood, and Haynes 2012). The second approach is bilingual according to which a more effective practice is when students develop native language skills along with a host country language skills (Sclafani 2017; Garsia 2016; Yalalov 2001; Canagarajah 2013, 14).

The second direction of teacher's work is academic support which is directed at reducing academic gaps. This is very important to immigrant children as they are behind at school because they lack language knowledge (Moskal 2014). The lack exists not only in the first but also in the second generation of immigrants (Christensen and Stanat 2007).

It is important to promote a relationship of trust in a class that includes immigrant children so they could feel comfortable (Birman and Tran 2015). This means building good communication and collaboration in a class (Gay 2002; Grant 2006). 
The most favorable environment for integration of immigrant children is multicultural environment which is known as intercultural education in the European scientific literature (Polat and Barka 2012) and policultural education in the Russian scientific literature (Gukalenko 2000). The essence of intercultural education is in teaching children mutual respect and tolerance to other cultures (Jantaand Harte 2016; Richards 2007; Sclafani 2017).

\section{FRAMEWORK}

This research is based on Vygotsky's sociocultural theory which considers learning and development as culturally, historically, and socially mediated process (Vygotsky 1956). The leading role in the child's education and development belongs to the adult - the teacher. According to the theory of multicultural education, the teacher should possess the knowledge and practices in order to implement multicultural programs (Gorsky 2009). Multicultural practices are defined as collaborative actions of teachers and students (Cvitillo et al. 2017).

\section{PURPOSE OF STUDY}

The need for this study arose because of the lack of research about teachers' experience in multicultural classes in Russia. Meanwhile, there is also the need for qualitative descriptive studies which improve understanding of how school teachers solve problems of integration of immigrant children (Sinkkonen and Kyttälä 2014; Alismail 2016). Previous quantitative study also showed that it is very difficult to identify without the use of qualitative methodology which methods teachers use to teach immigrant children (Gromova et al. 2019). The aim of the present research is to identify which educational practices elementary school teachers use with immigrant children. Our study focuses on understanding of how Russian educators solve problems of acculturation of immigrant children. The research isinitiated to fill the gap in the literature devoted to the study of educational practices used by teachers.

\section{METHOD}

This study used the descriptive and interpretive methodology (Hsiehand Shannon 2005; Creswell 2007; Graneheim and Lundman 2004).

\section{SETTING AND PARTICIPANTS}

Participants of the study were teachers from different cities of Tatarstan. Tatarstanis a multiethnic and multiconfessional region in Central Russia. According to the 2010 census, over 173 different nationalities live in the region, including 8 nationalities with more 
than 10.000 people (Tatars, Russians, Chuvash, Udmurts, Monrovians, Mari, Ukrainians and Bashkir). The majority of the population is represented by Tatars (ethnic Muslims) and Russians (ethnic Orthodox Christians). Tatarstan ranks sixth by the number of immigrants in the Russian regions. The overall number of registered immigrants in Tatarstan is 126.360 people most of whom are immigrant laborers $(36,631)$. There is no statistical data of immigrant children. During the research we asked teachers about the number of immigrant children in their schools and classes.

20 elementary school teachers with experience of working with immigrant children agreed to take part in the research. Some of them have attended career development courses (12 people) which are mandatory every five years for all teachers in Russia. Eight teachers worked in schools with a large number of migrant children. We learnt about those schools from our students who had internships there.

Table 1 - Demographic information about the participants

\begin{tabular}{|c|c|c|c|}
\hline $\begin{array}{c}\text { Age } \\
\text { (average/range) }\end{array}$ & $\begin{array}{c}\text { Experience } \\
\text { (average/range) }\end{array}$ & $\begin{array}{c}\text { Sex } \\
\text { (female/male) }\end{array}$ & $\begin{array}{c}\text { Place of residence } \\
\text { (Kazan/other) }\end{array}$ \\
\hline $46,26 / 31-56$ & $21,71 / 0,5-34$ & $19 / 1$ & $16 / 4$ \\
\hline
\end{tabular}

The majority of participants have worked in elementary schools for 0,5 to 33 years. One teacher is male, the rest are female. Ten participants are ethnic Tatar, eight are Russian, one participant is Mordovian. One of the teachers has immigrant experience as an immigrant from Kazakhstan. The majority of the teachers live and work in Kazan.

\section{DATA COLLECTION AND ANALYSIS}

Interview was used as a method for the empirical data collection. One-on-one interviews were conducted with the teachers who attended professional development courses. We also arranged interviewswith some teachers in their schools. During the interview we asked whether they have an experience of working with immigrant children. If they had such an experience we continued the interview. Participants gave their consents to be interviewed. Participants were informed that the conversation was recorded. They were also informed that no personal information (first name, last name, current occupation) would not be disclosed.

The participants were not informed about the purpose of the research in order to avoid socially desirable responses. Teachers usually think that the quality of their work is controlled; therefore they normally tend to think of teaching experiences that they do not even practice. The interview was prefaced with a researcher's statement: "We highly value your practical experience. It is very important to know the opinion of an experienced teacher about the difficulties you encounter when working with immigrant children. Please tell us 
about your experience of working with immigrant children". When teachers stated the countries the children arrived from and difficulties that they faced, we asked them about the ways they solved the problems and the ways they worked with the children. During interviews the teachers were allowed to express themselves freely, however, as a researcher I kept in mind questions which I wanted to receive answers for. If the teacher did nottalk about a certain topic, I asked specific questions from the list. For example,language learning question: "how do you help the student with learning the language"; question about immigrant children's school problems: "which problems in school do they face most often?"

The teachers willingly talked about children they work with, how they work with them and what difficulties they experience. Interviewslasted from 45 to 90 minutes.

The interviews were subsequently transcribed. The transcripts were read several times in order to get a general assumption about participants' feelings and perceptions. Every transcript had certain practice-related phrases or statements highlighted with color marker.

The data has been analyzed inductively and deductively. The deductive approach was based on the classification of practices suggested by Dumcius et al. (2012). They suggest distinguishing four categories of educational support for immigrant children: linguistic support, academic support, parental inclusion and intercultural education and positive school climate. We decided not to use "parental inclusion" as a separate category because during the coding process we realized that working with parents pursues different purposes. All other directions of teachers' work with immigrant children are related to the acculturation problems that they experience. Inclusion of parents in the educational process can be used for different directions of teachers' work, for example, language and academic support. Through inductive approach we found out that these directions contain different methods that teachers use in their work (inductive categories). Table 2 shows the frequency of phrases in the respondents' answers about the directions of their work. The frequency of inductive categories is specified in the parentheses in the text.

I. Language support. In 75 quotes the teachers talked about measures for teaching the Russian language and improvement of language skills. Only in one interview the teacher mentioned that the school organizes special Russian courses for immigrant children. In other cases teachers reported that language support is provided individually andas additional help. In this example, the teacher provides language support during the after-class activities. Interview 16:

We stayed after the class. I explained what she didn't understand in words and using gestures. During the after-classactivities we repeated everything we learned in class, in every subject. I explained all the topics again. We wrote dictations, keywords, small essays. Sometimes parents hire a tutor for additional classes. Interview 14: But the tutor is concerned with the main (Russian) language; they mostly tryto identify theknowledge gap and work on it. They read the tasks; try to understand what the student didn't get. 
One teacher said that such an approach is effective. Interview 16: "And this kind of individual work had the results".Some teachers, however, also mentioned that children learn the language faster through daily communication and TV than they do in school. Interview 6 :

I had one who didn't know the language. Spent a whole year in pre-school, we both struggled; he didn't know anything at all. His brother sat with him, explained and showed; he cried. And during the summer, just in three months, he learned to talk. He spent the whole summer on the street with kids and after that he started talking. He understood what we talked about.

As for the content of additional classes, teachers mostly say that they work with immigrant children on study materials orally and in writing. Students read, retell, and learn rhymes by heart. Work on literary texts includes explaining meaning of unknown words, picking synonyms for words, especially proverbs and sayings so that the child would not just read, but also understand what he is reading.Interview 12: Wework on texts during after-class hours, reading. We ask them to retell in order to develop the speech... We write dictations because it helps to remember". Interview 15: "I had to explain some words, mostly when we worked on vocabulary. Sometimes I have to explain Russian proverbs and sayings, of course, this is during individual work". Interview 14: "Right now we are working only on dialogues, so he could communicate and express his ideas.

Among communicative language training techniques teachers most often singled out communication with peers and teachers. Many teachers pointed out that children learnt the language faster through communication and games. Their vocabulary enlarges because they learn new words and repeat after their peers. Hence, many educators try to create conditions for children to communicate more: after-school activities, school camps, additional classes, stage plays, and social clubs. Interview 14: "I organize group work so that they couId talk more and help each other.Then, a preschool camp... to communicate with children and teachers".

Teachers also ask other immigrant children to help those who struggle with the language (10). Interview 8: "The kids who more or less understand Russian try to translate. They explain through gestures, pictures, put it in simpler words".

Meanwhile, the Tatar language knowledge helps to communicate with and explain to immigrant children with the poor knowledge of Russian. The Tatar language belongs to the Turkic language family, so it is similar to the native languages of children from Uzbekistan, Kyrgyzstan, Kazakhstan and Azerbaijan. Interview 19: "They can communicate through the Tatar language. The Tatar language teachers communicate easier with them, they also translate what we don't understand. The Turkic languages are similar". Interview 5: "Tatars and other pupils compare similar words in the classroom, it's interesting. There are similar words in the Kazakh and Uzbek languages." Interview 17: "No, they're the same Russian language teachers but they're ethnic Tatars and know Tatar well. And it's simpler for them 
to communicate with these students because they speak mostly Turkic languages. So, teaching Russian through Tatar".

Only one school providesimmigrant children with the Russian language courses. In other cases, many teachers believe such courses should exist but they do not specify what should be taught, which teaching methods should be used. Interview 15: "More focus on the Russian language. They won't learn the material without knowing Russian. Of course, we have the after-school class (Russian) but it's for all. We need a special one for these children". Only one teacher mentioned which teaching method would be the most appropriate which is teaching the language as foreign.

Teachers relate children's poor language skills mostly to low language skills of their parents. We, therefore, identified practices that involve parents. In one interview the teacher said that parents came to classes to learn the language. Interview 5: "But the child's mom brought a translator with her and learned in the back of the class". In other cases, teachers recommended the Russian language courses to parents. Interview 12: "Maybe teach parents, maybe after-class courses for parents, so parents can attend them with kids". Teachers talked about the need to work with parents, explaining to parents that they needed to convince children of the necessity to learn the language. Interview 4: "And I think that if an immigrant comes to school, we shouldn't take them to classaccording to the age, maybe to a younger class, but you have to explain this to parents". Interview 12: "I don't even know. Knowing the language to explain to the child. Talking to parents that it's necessary to study, that they also should put in some effort".

II. Academic support implies the measures that help in improving or supporting children's academic performance. As with the language support, teachers approach children individually, or parents hire tutors (30). Interview 3: "We explain itto someone individually. I can't do it when the whole class is present". Interview 12: "But some girls now have tutors, twice a week, they do homework with them". Interview 4: "Yes, additional explanation after classes, but sometimes they stay in the after-school clubs. They study there". Extra explainingtakes place during after-classactivities, after classes, during holidays. Interview 19: "We do homework with them during the after-classhours, I help them. Next day it's likestarting from a scratch. As our psychologist said, "don't be lazy". And it goes on and on day after day". Interview 18: "When I don't have a preschool camp, I invite them during summer and winter holidays for 2-3 hours".

During the class teachers explain the material in a simplified way, through visual aids, examples, actions or repeat the same material one more time if need be (4). Interview 9: "While explaining the topic I used graphics because childrenremember things better visually. They won't understand everything orally. If, let's say, it's related to math. One time a child didn't know the multiplication table. We did operations with numbers... All children understand numbers; they're the same in all languages. So I used graphics. Interview 11: "I pulled out 
my wallet and the coins, we added like that. They understood with coins, on the blackboard - no way". Interview 8: "I have to explain it on fingers and with pictures".

Two teachers said that additional classes and tasks are not necessary. Interview 2: "There is no need to give them additional tasks". Interview 6: "It is pointless to keep them after classes".

In some cases teachers manage to explain only with the help of a mediator. A mediator is normally a peer, either an immigrant or non-immigrant, as children use more simple language (5). Interview 9: "I asked other children to explain. Try to explain it. Children understand each other better. They talk differently, not using smart phrases like us. Asked classmates to explain on their own." Interview 6: "I try to put well-performing and poorly performing students in pairs, because children can explain to each other better." Interview 19: "When children got older, in third - fourth grades I started using the help of assistants. Assistants arewell-performing classmates. And well-performing immigrant children also became assistants, they helped too".

Teachers engage parents to improve students' achievements (11). Teachers explain parentsimportance of studying; they explain learning material to parents so they can explain it to their children. Interview 10: "If I call him, he comes and I explain. Dad would often make a brief visitafter the work". Interview 16: "And then I gave advice to the parents on how to work with children at home. I called them every day and explained everything. What we do at lessons, what we do after classes and what should be improved at home". Interview 9: "I talked about the importance of education at the teacher-parent meeting". Children do homework with parents. At the same time some parents often are not able to help their children with homework because of poor language skills, low education level.

Teachers also try to use an individual approach with children and adapt tasks according to the child's abilities. (5) Interview 18: "I almost never give them tricky tasks as homework, except maybe the simplest ones. It would be better at least if they could cope with the basic part of the curriculum. Simplified homework... For example, if Russians retell the whole text, I give them only a part of it". Interview 2: "If I'm asking to recite a poem, I do not ask them on that day. I know it will be difficult for them".

Teachers also try to give immigrant students better marks (8) if they see the benefit in doing so. Interview 18: "But I also tried to give better marks to motivate the child. I used to give B's for a dictation, even if there were 40 mistakes. I invented my own mark, pointed out typical mistakes and grouped them".

Usually teachers do it to encourage and inspire children (7). Interview 3: "But we make some excuses for them, of course. It's a must. If we give someone a $C$ for that number of mistakes, we can give a $B$ here. It's an encouragement". Sometimes teachers just give $C$ regardless of children's effort and improvement (1). Interview 4: "Yeah, just giving C's. For Math, Tatar, English they deserve it but Russian - no." 
III. Measures for promoting a favorable climate, the child's psychological comfort in the classroom.

Measures include teaching respect toward different ethnicities and developing skills of cross-cultural communication. These practices may sometimes coincide. For example, one teacher reported that she initiated a special club where children of different ethnicities can communicate. The teacher invites children of different nationalities, including immigrants in order to form a positive intercultural climate. Interview 5: "Our school has a social club called "Friendly Family". It's my personal initiative. The social organization (out of school) provides additional money. Children of different nationalities join the club. We get together once a month or once a week. We discuss world news, or we have kids who come up with something in their language and tell us. We try to attract kids who don't talk well, too". Then, there are practices for promoting a positive socio-psychological climate in class which are not related to the questions of cultural diversity (4) Interview 14: "I put children in contact so they could talk more and help each other". Interview 19: "And we give tasks. For example, we give out notebooks, collect notebooks. It may be a small task but it's still communication. I do everything to get them involved".

In order to teach children respect toward different ethnicities and create a culture of international communication, schoolsorganize national celebrations (5). Immigrant children recite poems, dance their national dances, sing national songs, and serve national dishes at such festivals. Interview 19: "Four times a year we organizea festival of different peoples where immigrant children represent their countries. Such events improve attitudes toward them. They wear their national costumes, read and sing in their languages, shownational dances". Interview 5: "I held an annual festival called "Me, you, he and she are a friendly family". We prepared it duringa year.I invited a Tajik boy who he told a poem, and a Tajik girl who danced in a long dress. There was an Uzbek girl and a boy. They performedanAzerbaijanian dance. There were national dishes of all sorts. A Georgian girl performed a Georgian dance, it was very melodic. We served the food and let everyone try".

Parents are also involved in the process ofintercultural dialogue. For example, one teacher mentioned that parents of native and immigrant children taught children differentcuisines, traditions and customs. Interview 5: "We visited a Russian family during the Easter, painted eggs and recorded it in on a camera. They told us about the origins of that holiday. Once an Azerbaijanian mom came and taught how to make cookies. She brought the dough and explained how it's served".

In two interviews teachers talked about the help that ethnic Diasporas in Kazan provide when children learn about different people's cultures; they also help to solve conflicts. Interview 5: "They have Sunday schools (in the Home of Ethnic's Friendship)". They gather there, many attend it. We have relationships with them and they always invite me with children. I can take any class and go there. Uzbeks, Ukrainians, Azerbaijanis. They perform at festivals, organize workshops and open classes. Sometimes they visit us, too." Interview 17: "Our school works 
together with the House of Ethnic's Friendship. We know each other and work with leaders of all Diasporas. Together we solve conflicts that could arise with some children's parents".

Teachers hold talks with entire classes as well as with immigrant (4.) They usually talk to the entire class to prevent discrimination against immigrant children. Interview 3: "We have no reproaches. I never allow to bully kids of different ethnicities". Interview 20: "A boy, Gabil, he's slightly darker than other kids... He was insulted. Researcher: "What did you do with this?" Teacher: I discussed itduring the class meetings. I had very few kids. It is convenient. It was the Tatar language class. All children are explained that they should help and support each other. Interview 8: "Of course, we tell children to support each other, so other children could help him, make friends, communicate. So he could help you, so you can collaborate. And children are trying to support. I let them know that they should support him". Teachers explain the principles of mutual respect and intercultural communication. Interview 19: "It's all different for everyone. From the very first grade I explain children and their parents that we all should live in friendship and agreement regardless of what nationality you are. I support tolerance and encourage our kids; I explain how hard it can be for migrant children".

Teachers hold individual talks with immigrant children because of their aggressive behavior (2). Teachers explain them that they should be friendlier. Interview 19: "I explain to them that they shouldn't get upset. Of course, it's difficult". Interview 14: "It's necessary to tune them inemotionally so that they would work and show respect". The need for talks is also caused by conflicts. In one of the interviews the teacher said that she talked not only to students but also to parents in order to solve a conflict between children. Interview 13: "Well, we talked, solved these conflicts. I called the parents, talked to dads and boys. We talked so they could feel comfortable in the classroom, change their opinions somehow. The dads sat against each other, Azerbaijanian and Tatar. I told them that if we can't find common grounds now, it would be impossible for the kids to study together".

Only in one interview a teacher mentioned the help provided by aschool psychologist when a child experienced problems communicating with other children. Interview 16 : "Well, we have a psychologist. She came up in the first class when one girl had problems with other children... She worked with her individually". Often teachers pointed out that there were no specialists who could help them in schools. Interview 6: "There should be a school psychologist. Specialists should be in a school".

\section{DISCUSSION AND CONCLUSION}

Most of the time teachers in Russia have to use additional individual work with immigrant children to teach them language and help them to improve their performance. On the one hand, teachers choose this way in countries without centralized models of transitional practices (Gorpas 2011). On the other hand, it is considered a very effective way for the child's development (Ferlisand Xu 2016; Birmanand Tran 2015). During additional classes teachers 
usually explain content of lessons one more time or work with texts, i.e. reading, retelling, composing dialogues without using special methods for teaching Russian as a foreign language. This is despite the fact that there are special instructions for teaching Russian as a second language developed by Russian educators (Levine, Lukens, andSmallwood 2013; Herrell and Jordan 2016; Kalenkova 2007; Kudryavtseva and Volkova 2013; Sineva O.V., Sineva V.S., and Kakorina 2016, Yalalov 2015). Teachers believe in the necessity of the Russian language courses, but only few of them are aware of the methods of teaching Russian as a foreign language (Gorpas 2011). Some teachers admit that they need to learn about teaching methods, special books, and guidelines for teaching immigrant children. This presents a challenge for teacher training institutions around the world, especially today, given the growing diversity.

An individual approach toward a child can be observed when teachers give immigrant children easier assignments and tasks. Teachers try to support children's tiniest achievements by giving them more accessible tasks considering their abilities. Previous studies have also provided the data about the importance of the entrance diagnostics, monitoring of the child's progress(Ferlis and Xu 2016; Moskal 2014). On the one hand, some researchers consider such practices as low expectations which lead to low performance (Brown and Medway 2007; Diamond et al. 2004; Brophy 2000). On the other hand, immigrant children cannot cope with difficult tasks because of poor language skills. Our research has also shown the necessity to develop and implement measures for the entrance diagnostic. These assessment tools are needed to determine the level of students' knowledge and skills when they enter the school.Students' achievements and academic progress should be monitored at the state level in order to avoid grade inflation and manage teachers' low expectations. Thus, it presents an additional problem for school teachers.

The role of the mediator between newly arrived immigrant children and their parents is played by children and teachers who know the Tatar language. This finding correlates with the results of previous studies which consider teaching a new language with the support of the native language as one of most effective strategies for the language adaptation. While the Tatar language is not native to many immigrant children it is close to the native language of many Turkic peoples who move to Russia and Tatarstan. Without formal language support teachers rely on assistants (Moskal 2014), mentors (Jantaand Harte 2016; Heckman 2008), or translators who are normally other immigrant children (Moskal 2014; Jantaand Harte2016). The teaching practice that implies organization of communication between peers and teachers helps to prevent segregation and avoid poor language environment (Moskal 2014, Sinkkonenand Kyttälä 2014; Jantaand Harte, 2016). In our study teachers reported asking peers not just to help organize language environment but also to explain lesson material because children talk to each other in plain language. This method is an important part of the cooperative learning and translanguating (Garsia 2016; Kagan, S. and Kagan, S. 1994). However, it is hard to detect in interviews whether teachers use this measure intentionally or are forced to do so out of tiredness and helplessness as all the support provided to migrant children stems out teachers' personal initiative. 
When we talk about ways of promoting positive climate in the classroom and psychological comfort for children, two directions can be singled out from the interviews. The first is creating environment for communication among children. The second is promoting respect for cultural diversity and cross-cultural communication (Banks 2004; Karuppiahand Berthelsen 2011; Robles, and Ostertag 1997). Although ethnocultural approaches are criticized as "touristic" toward different cultures (Derman-Sparks and Force 1989, 57), nonetheless, all children benefit from learning more about their own and other cultures (Richards, Brown, and Forde 2007; Ilinskaya 2008; LebedevaandTatarko 2009, Belyankova 2014). The experience of holding discussions with immigrant children and other students in order to reduce tensions, solve conflicts and encourage collaboration with parents is described in the literature. In addition to previous studies, it was found that the use of the potential of ethnic Diasporas is a good practice for acculturation of immigrant children and solving conflicts with their parents.

Without centralized support, teachers have to take the initiative when working with immigrant children. Although the data was analyzed using the deductive method, we also established that the ways teaching practices described in the literature are implemented have much more variations. The inductive analysis allowed us to confirm that the practice of parental inclusion can be used in all kinds of practices: academic and language support, promotion of a positive climate in the classroom. In the context of Tatarstan it is possible to teach the Russian language as a foreign language by means of the Tatar language which is close to the Turkic peoples.

\section{LIMITATION}

This study employed the qualitative method. Thus, the main limitation was the author's interpretation of the results and authors' subjective vision of teachers' and immigrant children's problems. In this research, we also relied on teachers' opinions and stories about their work. Although the interview content quite reliably described their experience, perceptions and feelings, the research could benefit if observation of teachers' practice is used. Theperspective of this research is identification of the factors affecting the use of practices, including relations between practices and teachers' attitudes.

\section{DISCLOSURE STATEMENT}

No potential conflict of interest was reported by the author.

\section{ACKNOWLEDGEMENT}

This work is performed according to the Russian Government Program of Competitive Growth of Kazan Federal University 


\section{REFERENCES}

ALEXANDROV, D.A., V.A.Ivanyushina, V.V.Kostenko, S.S.Savelieva, K.A. Tenisheva. 2012. The state of immigrant children in St. Petersburg. Moscow: UNICEF.

ALISMAIL, H. A. 2016. "Multicultural Education: Teachers' Perceptions and Preparation." Journal of Education and Practice 11(7): 139-146.

BANKS, J. A. 2004. Multicultural education: Historical development, dimensions, and practice. In Handbook of research on multicultural education, edited by J. A. Banks and C. A. M. Banks, 3-29. San Francisco: Jossey-Bass.

BELYANKOVA, N. M. 2014. "Некоторые формы организации внеурочных мероприятий в классах смешанного этнического состава." [Some organization forms of the events done in addition to class hours in classes of the mixed ethnic structure]. Elementary school 6: 94-95.

BIRMAN, D. 2002. "Refugee mental health in the classroom: A guide for the ESL teacher. Denver: Institute for Intercultural Learning". Available in: http://www.spring-institute.org. Accessed, February 28, 2013.

BIRMAN, D., and Nelly Tran. 2015. "The academic engagement of newly arriving Somali Bantu students in a US elementary school." Washington, DC: Migration Policy Institute. Available in: https://sites.education.miami.edu/refugeecollab/publications/.

BROPHY, J. 2000. Dispelling the myth: Teaching educational practices, series 1.

Washington: International Bureau of Education.

BROWN, K. E., andF. J. Medway. 2007. "School climate and teacher beliefs in a school effectively serving poor South Carolina (USA) African American students: A case study." Teaching and Teacher Education 23, 529-540.

CANAGARAJAH, A. 2013. Translingual practice: Global Englishes and cosmopolitan relations. Milton Park, Abingdon, Oxon: Routledge.Dworin, Moll, andSaez, 2001, p. 445.

CHRISTENSEN, G., andP.Stanat.2007. "Language policies and practices for helping immigrants and second-generation students succeed." The Transatlantic Taskforce on Immigration and Integration, Migration Policy Institute (MPI) and Bertelsmann Stiftung, 1-15. Available in: https:// www.naldic.org.uk/Resources/NALDIC/Research\%20and\%20Information/Documents/ChristensenEducation091907.pdf.

CIVITILLO, S., M. Schachner, L.Juang, F. J. van de Vijver, A. Handrick, and P. Noack. 2017. "Towards a better understanding of cultural diversity approaches at school: A multi-informant and mixed-methods study." Learning, Culture and Social Interaction 12: 1-14. doi: 10.1016/j.lcsi.2016.09.002.

CRESWELL, J. W. 2013. Qualitative inquiry and research design: Choosing among five approaches. Thousand Oaks, CA: Sage Publications.

DERMAN-SPARKS, L., and A. B. Force. 1989. Anti-bias curriculum tools for empowering young children. Washington: National Association for the Education of Young Childre. 1834 Connecticut Avenue, NW, Washington. 
DIAMOND, J. B., A.Randolph, andJ. P. Spillane. 2004. "Teachers' expectations and sense of responsibility for student learning: The importance of race, class, and organizational habitus." Anthropology and Education Quarterly, 35(1), 75-98.

DUDKO, S. A. 2014. “Квопросуобобучении детей мигрантов в России.”[On the issue of teaching the immigrant children in Russia]. Values and Meanings 3 (31).

DUMCIUS, Rimantas, Ides Nicaise, IndreBalcaite, JanaHuttova, and Hanna Siarova. 2012. "Study on educational support for newly arrived migrant children." European Commission; Brussels. Available in: https://limo.libis.be/primo-explore/fulldisplay?docid=LIRIAS1897394andcontext=Landvid=Liriasandsearch_scope=Liriasandtab=default_tabandlang=en_US.

FERLIS, E., and Y.Xu. 2016. "Prereferral process with Latino English language learners with specific learning disabilities: Perceptions of English-as-a-second-language teachers." International journal of multicultural education 18(3): 22-39.

GARCÍA, O., H. H. Woodley, N. Flores, and H. Chu. 2016. "Latino Emergent Bilingual Youth in High Schools: Transcaring Strategies for Academic Success." Urban Education 48(6): 798 -827. doi: $10.1177 / 0042085912462708$.

GAY, G. 2002. "Culturally responsive teaching in special education for ethnically diverse students: Setting the stage." International Journal of Qualitative Studies in Education 15(6): 613-629. doi: 10.1080/0951839022000014349.

GIBBONS, P.(2015. Scaffolding language, scaffolding learning.Teaching English Language Learners in the Mainstream Classroom.Second edition. Heinemann Portsmouth, $\mathrm{NH}$. Available in: https://assets.pearsonschool.com/asset_mgr/current/201511/gibbonschapter.pdf.

GRANT, C. A., and M. Gillette. 2006. "A candid talk to teacher educators about effectively preparing teachers who can teach everyone's children." Journal of Teacher Education 57(3): 292-299.

GORPAS, R. and A. Triandafylliou. 2011. "Greek education policy and the challenge of migration: an 'intercultural' view of assimilation." Race, Ethnicity and Education 14(3): 399-419.

GORSKI, P. C. 2009. "What we're teaching teachers: An analysis of multicultural teacher education coursework syllabi." Teaching and Teacher Education 25(2): 309-318.

GRANEHEIM, U. H., and B.Lundman.2004. "Qualitative content analysis in nursing research: concepts, procedures and measures to achieve trustworthiness." Nurse education today 24(2): 105-112.

GROMOVA, C.,R.Khairutdinova, D.Birman, A.Kalimullin."Teaching Technologies for Immigrant Children: An Exploratory Study of Elementary School Teachers in Russia" (in press). Intercultural Education 30 (5).

GUKALENKO, O.V. 2000. Теоретикометодологическиеосновыпедагогическойподдержкидетей мигрантоввполикультурнойобразовательнойсреде[Theoretic-methodological basics of pedagogical support and defense of immigrant students in policultural educational environment]. Rostov-onDon: Rosmen. 
HECKMAN, F. 2008. "Education and Migration: Strategies for Integrating Migrant Children in European schools and Societies." Accessed, April, 2008. Retrieved from: http://www.nesse.fr/ nesse/activities/reports.

HERRERA, Sr, J. C. 201). "Teacher beliefs and practices: Their effects on student achievement in the urban school setting." Doctoral diss., Kansas State University). Available in: http:// krex.k-tate.edu/dspace/bitstream/handle/2097/3889/JohnHerrera2010.pdf?sequence=7.

HERRELL, A. L., and M. Jordan. 2016. 50. Strategies for teaching English language learners (5th ed). Boston, MA: Pearson.

HSIEH, H. F., and S. E. Shannon. 2005. "Three approaches to qualitative content analysis." Qualitative health research 15(9): 1277-1288.

ILYINSKAYA, I. P. 2008. "Воспитаниевполикультурнойсредесредстваминародныхсказок” [Education of elementary school pupils in the polycultural environment]. Elementary school 5: 14-15.

JANTA, B., andE.Harte. 2016. "Education of Migrant Children: Education Policy Responses for the Inclusion of Migrant Children in Europe." Research Report. RAND Europe. Available in: https:// www.rand.org/content/dam/rand/pubs/research_reports/RR1600/RR1655/RAND_RR1655.pdf

KAGAN, S., and S. Kagan.1994. Cooperative learning (Vol. 2). San Juan Capistrano, CA: Kagan Cooperative Learning.

KALENKOVA, O.N. 2007. Уроки русской речи[Russian language lessons]. Moscow: Etnosfera.

KARUPPIAH, N., and D. Berthelsen. 2011. "Multicultural education: The understandings of preschool teachers in Singapore." Australasian Journal of Early Childhood 36(4): 38-42.

KUDRYAVTSEVA, E. L., T. V. Volkova, and E. A. Yakimovich. 2013. Обучение русскому языку в билингвальной среде. Рекомендации [Teaching Russian in the bilingual environment. Recommendations]. Moscow: CSOT.

LEBEDEVA, N.M. and A.N. Tatarko. 2009. Стратегии межкультурного взаимодействия мигрантов и населения России [Strategies for intercultural interaction of migrants and the population of Russia]. Moscow: RUDN.

LEVINE, L. N., L. Lukens, and B. A. Smallwood. 2013. The GO TO strategies: Scaffolding options for teachers of English language. Retrieved from: https:////www.cal.org/excell.

LEVINE, L. N., Smallwood, B. A., and Haynes, E. F. (2012). Listening and speaking: Oral language and vocabulary development for English language learners. Hot Topics in ELL Education. Washington, DC: Center for Applied Linguistics.

MOSKAL, M. 2016. "Language and cultural capital in school experience of Polish children in Scotland." Race Ethnicity and Education19(1): 141-160. Available in: http://dro.dur.ac.uk/21747/1/21747.pdf.

POLAT, S., and T. O. Barka. 2012. "Multiculturalism and Intercultural Education: A Comparative Study with a Sample of Swiss and Turkish Candidate Teachers." World Applied Sciences Journal 18(9): 1180-1189. doi: 10.5829/idosi.wasj.2012.18.09.1242. 
RAVIV, A., G. Keinan, Y. Abazon, and A. Raviv. 1990. "Moving as a stressful life event for adolescents." Journal of Community Psychology 18: 130-140.

RICHARDS, H. V., A. F. Brown, and T. B. Forde. 2007. "Addressing diversity in schools: Culturally responsive pedagogy." Teaching Exceptional Children 39(3): 64-68.

ROBLES DE MELENDEZ, W., and V. Ostertag. 1997. Critical multiculturalism: rethinking multicultural and antiracist education. Boston, MA: Delmar Publishers.

SCLAFANI, C. 2017. "Strategies for Educators of Bilingual Students: A Critical Review of Literature." International Journal of Education and Literacy Studies 5(2): 1-8. doi: 10.7575/aiac. ijels.v.5n.2p.1.

SINKKONEN, H. M., and M. Kyttälä. 2014. "Experiences of Finnish teachers working with immigrant students." European Journal of Special Needs Education 29(2): 167-183. doi: 10.1080/08856257.2014.891719.

THE MINISTRY OF INTERNAL AFFAIRS OF RUSSIAN FEDERATION. 2018. Statistical information on migration situation. Available in: https://xn--b1aew.xn--1ai/Deljatelnost/statistics/migracionnaya/ item/14852910.

“THE FEDERAL LAW ON EDUCATION № 273.”2013. Available in: http://zakon-ob-obrazovanii.ru/.

SINEVA, O.V., V.S.Sineva, E.V. Kakorina. 2016. Русский язык в разноуровневом поликультурном классе: технологии языковой адаптации. Книга для учителя [Russian language in multilevel policultural class: technologies of linguistic adaptation. Book for teacher.].Moscow: GAOU VO MIOO.

VEDDER, P., M. Boekaerts, and G. Seegers. 2005. "Perceived social support and wellbeing in school: The role of students' ethnicity." Journal of youth and adolescence 34(3): 269-278.

VYGOTSKY, L.S. 1956. Main psychological proceedings: Thinking and Speech: The problem of child's psychological development. Moscow: APN RSFSR.

YALALOV, F.G. 2001. “Становление и развитие национального гимназического образования: Диссертация доктора педагогических наук" [Formation and development of the national gymnasium education: Ed. Doctoral dissertation] Kazan. Retrieved from: https://elibrary.ru/item. asp?id=15990263.

YALALOV, F.G. 2015. “Многомерность содержания профрессионального образования” [Multidimensionality of the content of professional education] Bulletin of the Adygea State University. Series 3: Pedagogy and psychology 1 (157): 126-131. Retrieved from: https://www.elibrary.ru/item. asp?id=23562662.

ZBOROVSKY, G. E., and E.A. Shuklina.2013." Обучение детей мигрантов как проблема их социальной адаптации" [Training of migrant children as problem of their social adaptation]. Sociological researches 2: 80-91. 
ZHELEZNYAKOVA, E. A. 2012. “Детимигрантов в современнойроссийскойшколе: Путиязыковойадаптации" [Children of migrants at modern Russian school: ways of language adaptation]. News of Penza state pedagogical university 28: 774-778.

ZHUKOVA, I.A. 2015. “ОфициальныйстатусдетеймигрантоввРоссийскойФедерации” [The legal status of immigrant children in Russian Federation]. Russia. XXI Century (2): 38-40. 